Utah State University

DigitalCommons@USU

8-12-2020

\title{
Assessing Research Compliance for Federally Funded Projects: The Good, the Bad, and the Publicly Accessible
}

\author{
Rebekah Cummings \\ Utah State University \\ Lindsay E. Ozburn \\ Utah State University \\ Andrea Payant \\ Utah State University \\ Betty Rozum \\ Utah State University \\ Michael Shelton \\ Utah State University \\ Ryan Bushman \\ Utah State University \\ Follow this and additional works at: https://digitalcommons.usu.edu/lib_pubs \\ Part of the Library and Information Science Commons
}

\section{Recommended Citation}

Cummings, R., Ozburn, L., Payant, A., Rozum, B., \& Shelton, M. (2020) "Assessing Research Compliance for Federally Funded Projects: The Good, the Bad, and the Publicly Accessible." Journal of Library Administration 60(7). https://doi.org/10.1080/01930826.2020.1786985

This Article is brought to you for free and open access by the Libraries at DigitalCommons@USU. It has been accepted for inclusion in Library Faculty \& Staff Publications by an authorized administrator of DigitalCommons@USU. For more information, please contact digitalcommons@usu.edu.

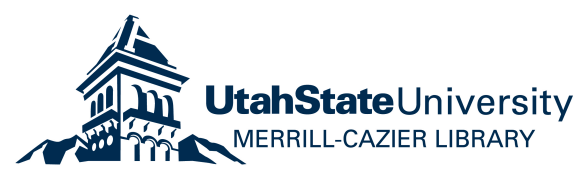




\section{Assessing Research Compliance for Federally Funded Projects: The Good, the Bad, and the Publicly Accessible}

Rebekah Cummings ${ }^{\mathrm{a}}$, Lindsay Ozburn ${ }^{\mathrm{b} *}$, Andrea Payant ${ }^{\mathrm{b}}$, Betty Rozum ${ }^{\mathrm{b}}$, Michael Shelton ${ }^{\mathrm{b}}$, and Ryan Bushman ${ }^{\mathrm{b}}$.

${ }^{a} J$. Willard Marriott Library, University of Utah, Salt Lake City, Utah, USA

${ }^{b}$ Merrill-Cazier Library, Utah State University, Logan, Utah, USA

*Correspondence may be directed to Lindsay Ozburn at Utah State University Merrill-Cazier Library, 3000 Old Main Hill Logan, Room 118, UT 84321 or to lindsay.ozburn@usu.edu.

Rebekah Cummings

Digital Matters Librarian

University of Utah, J. Willard Marriott Library

295 South 1500 East, Salt Lake City, UT 84112

rebekah.cummings@utah.edu

+1 (801) 581-7701

ORCiD: 0000-0003-3457-2050

Lindsay Ozburn (Corresponding Author)

Assessment Coordinator

Utah State University Merrill-Cazier Library

3000 Old Main Hill, Room 118

Logan, UT 84321

lindsay.ozburn@usu.edu

+1 (435) 797-0202

ORCiD: 0000-0002-0111-7265

Andrea Payant

Metadata Librarian

Utah State University Merrill-Cazier Library

3000 Old Main Hill

Logan, UT 84322

andrea.payant@usu.edu

ORCiD: 0000-0001-9873-1538

\author{
Betty Rozum \\ Data Librarian \\ Utah State University Merrill-Cazier Library \\ 3000 Old Main Hill \\ Logan, UT 84322 \\ betty.rozum@usu.edu \\ ORCiD: 0000-0001-9367-8424
}

Michael Shelton

Research Data Library Assistant

Utah State University Merrill-Cazier Library

3000 Old Main Hill

Logan, UT 84322

michael.shelton@usu.edu

ORCid: 0000-0002-3561-3937

Ryan Bushman

Data Analytics Assistant

Utah State University Merrill-Cazier Library

3000 Old Main Hill, Room 239

Logan, UT 84322

ryan.bushman@usu.edu

ORCid: 0000-0001-9278-2000

Rebekah Cummings is the Digital Matters Librarian in the J. Willard Marriott Library at the University of Utah.

Lindsay Ozburn is an Assistant Librarian and Assessment Coordinator in the Merrill-Cazier Library at Utah State University.

Andrea Payant is the Metadata Librarian in the Merrill-Cazier Library at Utah State University.

Betty Rozum is Data Librarian in the Merrill-Cazier Library at Utah State University.

Michael Shelton is the Research Data Library Assistant in the Merrill-Cazier Library at Utah State University.

Ryan Bushman is the Data Analytics Assistant in the Merrill-Cazier Library at Utah State University

Word Count $=7,970$ 


\begin{abstract}
In 2016, Utah State University launched a program to ensure their campus' federal grant recipients were in compliance with funder mandates to share any data or publications produced as a result of the award. This paper discusses how a cross-institutional team of librarians and administrators evaluated the success of this program using online asynchronous focus groups (OAFG) in conjunction with a traditional survey. The challenges and successes of using OAFGs to assess library services are also examined. An OAFG gave participants greater convenience, flexibility, participation, and time to craft answers, eliminating some of the hurdles to traditional focus group participation.
\end{abstract}

Keywords: research data management, assessment, online asynchronous focus groups (OAFG), grant compliance

\title{
Introduction
}

In February 2013, the U.S. Office of Science and Technology Policy issued a Memorandum that dictated new data management terms for federal grant recipients (Holdren, 2013). The Memorandum - known as the OSTP Memo - was issued to help increase communal access to data that culminated from publicly funded research. Providing communal access to such research helps further scientific output by eliminating proprietary barriers that sometimes exist with scholarly outputs. However, it can be challenging for researchers to ensure data and publications from such research are made publicly available. The process often involves data management and deposit processes (e.g., data curation and metadata management) with which researchers are often unfamiliar. Such roadblocks decrease the likelihood of compliance with the federal 
mandates or result in convoluted data files that are difficult to understand or reproduce. As the reproducibility of empirical results is a cornerstone of research quality, validity, and consistency across and within disciplines, a lack of compliance and lack of carefully curated datasets can prove problematic.

In 2015, Utah State University (USU) formed a small team from members of a larger campuswide Data Task Force to develop a program that would allow the University to monitor and assist researchers with meeting the terms of the funder mandates. The cross-campus collaborative program has been operational since Fall 2016 and includes a mix of librarians and campus administrators. The premise of the program is that the institution's Sponsored Programs Office - a division within their Office of Research - and the Library offer technical support and reminders to the Principle Investigator (PI) throughout the lifecycle of their award (see Figure 1). Together their support encourages compliance with the funder's mandate to make publications or research data available and adherence to the terms of the data management plan the PI submitted with their proposal. The process requires close communication between the Office of Research, the Library, and the PI. The program process has remained mostly unchanged since its inception and description in Broadbent et al. (Broadbent et al., 2018).

After three years of operation, an assessment of the program was in order. A small assessment team comprised of members of the Data Task Force and library assessment specialists developed and executed a two-pronged assessment which included a survey (see Appendix A) and an online asynchronous focus group (OAFG) with questions triangulated from the survey (see Appendix B). The assessment team invited campus researchers who had previously received federal grants 
to participate in the survey and focus group. Both the survey and the OAFG were ideal assessment methods, capturing data with depth and breadth. The survey provided informative data from a larger population, and the focus group provided deeper, substantive explanations to survey responses. Additionally, the variety of assessment methodologies afforded flexibility for the participants' schedules. This paper describes the program and discusses the method of assessment, findings, and changes the institution plans to implement.

\section{[Insert Figure 1]}

\section{Literature Review}

\section{Assessing the compliance of federal mandates}

The reproducibility of empirical results is a cornerstone of research quality, validity, and consistency across and within disciplines. It is a key issue discussed in any discipline that takes part in empirical research (Popper, 2005). For academic libraries, Vitale (2016) notes that research reproducibility has become more of a hot topic in recent years with libraries examining what role they might play in assisting their campus' researchers with the reproducibility and accessibility of empirical research (Vitale, 2016). Such involvement from libraries demonstrates a shift in academia. This shift is apparent as academic libraries become increasingly more engaged with campus research efforts. The approach propels academic libraries into a new realm of usefulness and relevance, affording the opportunity for librarians to step out of a support role and edge closer to being partners in research. 
Beginning in the early 2010s, federal organizations began implementing new mandates requiring grant recipients to ensure research reproducibility and accessibility by-way-of data management plans (DMP) and data deposit requirements. Similarly, the National Institutes of Health (NIH) and the Agency for Healthcare Research and Quality (AHRQ) updated their proposal instructions that require applicants to describe their research design in an effort to ensure reproducibility (Vitale, 2016). Vitale (2016) explains that libraries and library organizations prepared technical infrastructure for years before the National Science Foundation's (NSF) release of its DMP requirement in 2011; and, in response to the later NIH and AHRQ application updates, research and data management services (RDMS) within academic libraries emerged to support their campus academics throughout the research lifecycle. The efforts position librarians as helpful contributors in the research and publication process.

Almost ten years later, librarians and professional library organizations are more involved than ever in shaping policy and best practices for RDMS in support of researchers. In Fall 2018, the Association of Public and Land Grant Universities (APLU) and the Association of American Universities (AAU) held an NSF Sponsored Workshop on Accelerating Public Access to Research Data (Redd et al., 2019). The workshop was designed to facilitate discussion among attendees - librarians included - about the process in place and under development at their institutions for providing public access to research data. Each team was also tasked with developing a plan for their institution to further their research data efforts for the next year.

In January 2020, the Association of Research Libraries (ARL) made public their comments on NIH's ‘Draft Policy for Data Management and Sharing' for which NIH solicited public 
feedback. In their press release, the ARL offers support for many of NIH's new data policies for grantees; namely, they support the inclusion of guidance for common data elements and standards for scientific data, consistency of guidance and rules for grantee's data management across other federal agencies, and the inclusion of funding lines within grant monies to pay for RDMS support (Association of Research Libraries (ARL), 2020).

Even before this press release was made public, library practitioners and university administration questioned the impact of RDMS and the extent to which they have influenced campus researchers to comply with federal grant mandates. Assessing the compliance of deposit mandates for federal grants is a sparsely explored topic in the literature - particularly, the effectiveness of RDMS. Given the increasing involvement of librarians and library institutions in this discussion, evaluation of RDMS efforts will be important moving forward. This study addresses the gap in the literature by providing methodology to assess researchers' compliance with federal mandates to deposit research data into public repositories.

\section{Focus groups as a methodology}

Researchers have long utilized group research to explore people's attitudes, behaviors, and opinions on any given topic (Krueger, 1995; Robinson, 1999; Sim, 1998; Twinn, 1998). Generally, in-person group research - also known as focus-groups - quickly reveal similarities and differences in opinions, perspectives, preferences, and behaviors on the topic discussed (D. W. Stewart \& Shamdasani, 2017). In social science research, focus groups are traditionally "characterized as an organized group discussion around a given topic, which is monitored, guided if necessary, and recorded by a researcher" (K. Stewart \& Williams, 2005a). As Stewart 
and Williams note, they are particularly distinguished through the use of group interaction to obtain data that is more deeply focused than survey data (K. Stewart \& Williams, 2005a).

In contrast to surveys, which are typically meant to find broad conclusions with data that can sometimes be generalized to a particular population, focus-groups take a deep dive into pointed questions and inexplicable trends arising from survey data. While focus-group data typically should not be generalized to a larger population, it can capture very complex attitudes and opinions that surveys cannot. Even though the limitations of focus groups are widely known (i.e., the use of small convenience samples and the influence of context and body language on group dynamics), they remain an important tool for researchers looking to involve users and consumers in product design and research (D. W. Stewart \& Shamdasani, 2017).

The rise of faster, more efficient internet has made it possible to institute user-based research, such as focus groups, online. As it spreads into many corners of the world, the internet provides access to larger populations scattered across different geographic regions that were previously inaccessible to researchers. Capitalizing on this globalization, advertising, market researchers, and health professionals, in particular, have all found utility in pursuing online-based group research to more accurately inform their studies and reach larger user bases. Academia began capitalizing on this new virtual landscape in the 1990s (see Murray's 1997 study on using virtual focus groups in qualitative research), employing qualitative and quantitative research methods online to reach large users bases (K. Stewart \& Williams, 2005a). 
There are several examples in literature documenting how internet-based research methods have enhanced qualitative research (Matthews \& Cramer, 2008; O'Connor \& Madge, 2003; Tuttas, 2015). More specifically, several researchers point to the effectiveness of technology in carrying out synchronous (real time) focus group research (Gaiser, 1997; Kenny, 2005; K. Stewart \& Williams, 2005b; Stover, 2012; Williams et al., 2012). Some of this literature, emerging over the last twenty years as a result of online methods being honed and further explored, delves deep to examine the effectiveness of the different modes of focus group operation: asynchronous or synchronous (K. Stewart \& Williams, 2005b; Stover, 2012; Williams et al., 2012; Zwaanswijk \& van Dulmen, 2014).

Asynchronous (not-real-time) focus groups, as opposed to synchronous focus groups, can eliminate time zone and recruitment barriers through the use of discussion threads, email correspondence, LISTSERVs, and chat rooms (Hamilton \& Bowers, 2006; Tuttas, 2015; Watson et al., 2006). Williams et al.(2012) note that the written, anonymous capabilities of asynchronous focus groups can greatly increase self-disclosure, as well as thoughtful and reflective responses that in-person or synchronous online focus groups do not typically enable. Stewart and Shamdasani note that the potential anonymity of online groups may make participants more willing to express honest opinions on sensitive topics, such as suicide (Han et al., 2019), health and wellness experiences in the LGBTQ plus community (Ramo et al., 2019), if the online environment is appropriately structured (D. W. Stewart \& Shamdasani, 2017).

Additionally, Zwaanswijk and van Dulmen's study verifies that participants appreciate the flexibility of asynchronous focus groups which allow them to participate when and where it is 
most convenient for their schedules (2014). In the context of this paper, accommodating the busy schedules of academics was one of the researchers' key concerns, resulting in the utilization of asynchronous focus groups as one of the research methods for the study.

However, it is important to weigh such advantages against the possibility of participants not accurately portraying themselves or betraying the anonymity of other participants by allowing a non-participant access to online conversation threads (whether because of duplicitous reasons or accidental) (D. W. Stewart \& Shamdasani, 2017). Greenbaum (2008) argues that online focus groups should not even be called focus groups, as they lack key characteristics that make focus groups unique (e.g., security considerations, feeling and experiencing the atmosphere within a group, group dynamics as a part of the process, the ability to use external stimuli with the participants, etc.).

Williams et al. (2012) argue that asynchronous methods must be considered carefully in line with the study design. Asynchronous methods run the risk of negating the traditional benefits of inperson and synchronous focus groups such as the impact of serendipitous group dynamics on the data collection process. The interpretation of another participant's comments, for instance, can vary greatly based on personality, life experiences, and familiarity with electronic communication. Participants' familiarity with online discussions must be considered in the study design; otherwise the researchers run the risk of the particulars of the methodology overshadowing the data collection (Williams et al., 2012). 
Similar to in-person focus groups, social cues and context can both drive conversations and influence it in unpredictable ways. Hoffman, Novak, and Stein's research (Hoffman et al., 2013) on digital consumers questions how online content such as reviews, a friends' behavior or online profile, or targeted ads, shape the creation and consumption of online content and subsequent user behavior. Identifying and navigating the influence of social cues is therefore important to the integrity of one's data from online group research.

\section{Methods}

A small assessment team was compiled to evaluate the institution's efforts in assisting researchers with their data sharing requirements. The team was comprised of the institution's Data Librarian, Metadata Librarian, Data Librarian Assistant, and Data Analytics Assistant. The assessment team felt that assessing the program would require a two-pronged approach: a survey distributed to a larger population of campus researchers (see Appendix A) and an online asynchronous focus group (OAFG) targeting a smaller subsection (see Appendix B). Input concerning the survey was received from the USU's Library Assessment Coordinator. To mediate the OAFG and ensure participant confidentiality, the assessment team acquired the assistance of the University of Utah's (U of U)-Digital Matters Librarian.

\section{Survey methods}

As part of the two-pronged assessment, the survey allowed for all researchers affected by federal mandates to have the opportunity to participate in providing feedback. RMDS identified 78 researchers the institution for the survey sample that had previously received or were currently receiving funding related to a tracked award between 2016 (the beginning of the RDMS 
program) and Fall 2019. Only researchers whose awards were subject to the 2013 OSTP memorandum were included in this list. USU's Internal Review Board (IRB) was contacted to determine if specific protocols were required. Since the purpose of the survey was to serve solely as a programmatic assessment, IRB oversight was unnecessary.

The assessment team designed and administered the survey using Qualtrics. The survey, as shown in Appendix A, was composed of fifteen questions, including an informed consent introducing the purpose, procedures, risks, benefits, and confidentiality procedures. Opening questions were used to establish researchers' experience levels and their data and publication depositing habits. The questions following were designed to ascertain researchers' opinions concerning the annual reminder emails sent by the Sponsored Programs Office (SPO) and RDMS on the anniversary of their awards. These emails serve as a reminder that the researchers need to annually update their information concerning what data and publications they have created and deposited related to their awards. Finally, the researchers were asked if and how they thought that SPO and the Library could better facilitate their individual efforts to meet funder mandates. Invitations to participate in the survey were emailed to the list of possible researchers.

The assessment team acquired assistance from members of USU's Mathematics and Statistics Department to ensure that the survey results were properly interpreted. The raw data from Qualtrics was cleaned for use in SAS, a statistical analysis program.

\section{Focus group methods}


The assessment team triangulated questions and data from the survey to create the OAFG questions (see Appendix B). An online asynchronous focus group (OAFG) was chosen in lieu of a traditional focus group to accommodate the busy schedules of participants and to allow for time and space for them to be thoughtful in their responses. An additional benefit of using an OAFG is that written contributions would yield immediate data and reduce transcription time and error.

Once the assessment team chose an OAFG as the qualitative research method, a convenient, easily accessible, and comfortable space was sought for participants to provide both positive and negative feedback. The assessment team secured a data librarian external to the institution to serve as a neutral moderator - U of U's Digital Matters Librarian. Canvas was selected as the OAFG platform because of its secure virtual space supported by both USU and U of U. Canvas met all the necessary technical requirements including the ability to capture and facilitate multiple discussions, respond directly to prompts or in-line with other participants, and keep the data secure until it had been de-identified. As the course management system used by both institutions, both the moderator and participants were familiar with the system and had access to technical support at their institutions. One drawback to Canvas was the inability to export the discussion threads out of Canvas into a .csv file or Excel spreadsheet. The focus group moderator addressed this barrier by cutting, pasting, and de-identifying the data as she moved it out of Canvas.

The Canvas site included a landing page that directed participants to information about the purpose of the study, ground rules for participation, and privacy and consent. This information 
was provided textually and through a four-minute video prepared by the moderator. From this page, participants could access the Discussion page, which included one introduction thread and four discussion threads on specific topics with detailed prompts. As shown in Appendix B, the four topics included: researcher response to funder mandates, researcher practices regarding data and publication, research office and library program, and what would help researcher data practices and compliance moving forward. Topics prompts were triangulated with the survey questions for more accurate data comparison and analysis.

For the first attempt at conducting an OAFG, fifteen survey respondents were selected at random to participate. Via an email message, USU's Vice President for Research invited the fifteen participants to join the OAFG at their convenience the following day. The assessment team's hope was that roughly half of the participants would be able to contribute some feedback. Unfortunately, the team underestimated the importance of giving significant lead time to the participants. With only a single day's notice, only two of the fifteen participants responded and even they were inexplicably unable to enter the Canvas site despite the fact that the site had been tested in advance. In short, the first attempt at an OAFG was a failure.

Determined to learn from mistakes, the assessment team set a second date for an OAFG with the intention of giving several weeks of notice to participants, confirming attendance in advance, and lowering barriers to entry on the Canvas site. First, the Canvas site was moved from the moderator's U of U instance to a local USU instance so that participants could easily enter the site without permission issues. The moderator was able to work with a USU Canvas administrators to move the existing Canvas site and secure administrative privileges. Then, on 
October 30, 2019, the USU Vice President for Research invited the same fifteen participants to participate in an OAFG on November 21-22 stressing the asynchronous nature of the group and that they could participate at their convenience. Of the 15 invited participants, five accepted the invitation, four declined, five failed to respond, and one left the university. Ultimately, only three participants participated in the focus groups and one answered the prompts via email. Once the window of participation for the OAFG closed, the moderator de-identified the data, coded the data into themes, extracted notable quotes, and shared the data with the rest of the assessment team.

\section{Results}

Research results are broken down into three categories that correspond with questions from the survey and prompts from the focus group discussion: Profile of the Researcher, Behavior of the Researcher, and Responses to the Research Office, Sponsored Programs, and the Library Efforts.

Results from the online survey and focus groups are reported below. A member of the assessment team used SAS to create a series of two-way frequency tables demonstrating the relationship of the researchers' responses to the various questions. Additionally, he created bar charts to give visual context for the frequencies to the responses received concerning the researchers deposit habits.

Qualitative data from the focus groups was coded into themes identified by the focus group moderator. The six themes that were extracted after coding were: 
(1) Praise for the Data Librarian, the library, and the research office (16 statements)

(2) Data sharing challenges (6 statements)

(3) Data resources (such as DMP Tool, FigShare, Digital Commons, Metavist, Morpho) (10 statements)

(4) Appropriate time to make data available (6 statements)

(5) Open Access (7 statements)

(6) Actionable steps USU can do to help researchers (6 statements)

The comments are useful to gain insight into the process and the perspectives of the participants, but no in-depth analysis was performed on the focus group data due to the small sample size. Even though data gathered via focus groups is not representative of the entire research population, it provided an opportunity for the assessment team to hear how participants interpreted their own experiences managing and sharing data and using USU's-data services.

\section{Profile of the Researchers}

The survey was emailed to 78 participants. Twenty-seven people completed the survey, representing $34.6 \%$ of the total population. Although findings cannot be generalized to the entire population, the information gained through this survey is still very beneficial and has provided information that will guide changes.

The respondents varied in years of experience from three to 33 years with a mean of 18.7 years. Of the respondents, 19 of the $27(70.4 \%)$ respondents indicated they had three or fewer awards 
that required deposit of publications into a public access repository and 18 of the $27(66.67 \%)$ respondents indicated they had three or fewer awards that required deposit of data into a publicly accessible repository.

As stated above, fifteen researchers were selected at random to participate in the online asynchronous focus group. Of the fifteen invited participants, three provided robust qualitative data. By coincidence, the profile of the researchers who participated in the OAFG was strikingly similar; they are all tenured, midcareer female scientists who received their PhDs between 12-17 years ago. Two of the participants had managed between 3-5 awards in their careers while the third participant reported managing between 20-30 awards during her career. All had worked with the SPO and had experiences making their data openly available.

\section{Behavior of the Researcher}

Researchers were asked how often they made data available during their careers as a requirement prescribed by journal publishers. Four respondents indicated they had never made data available for this purpose. When asked about making data available to satisfy funder mandates, only two respondents indicated they never made data available to satisfy a funder. In both instances, the majority of respondents made data available at least once in order to follow journal publishing requirements $(84.6 \%)$ or to satisfy a funder $(92.6 \%)$. Figure 2 below shows the percentage of respondents making dating open during their career.

[Insert Figure 2] 
Of 26 respondents (one respondent did not answer this question), 16 have made data available at least once just for the sake of making it public (61.5\%) while 10 never did so $(38.5 \%)$.

When asked how long, after the close of their award, the researcher anticipated producing or did they generally produce journal publications, $92.59 \%$ responded up to five years after the close of the award.

When asked how long, after the close of their award, the researcher anticipated they would need to have their final data ready for deposit in public repository, $88.46 \%$ anticipated needing up to 4 years after the close of the award to have final data ready. Figure 3 below shows the distribution.

\section{[Insert Figure 3]}

The focus group revealed that although all three of the participants had made data openly available, they did not have a generally favorable perception of open data sharing. All three had made data available to fulfill requirements from their funding agency or publication but raised a wide variety of objections to open data sharing including plagiarism, the competitive nature of research, size of data, time it takes to prepare data, backing up data, clunky repository interfaces, and metadata challenges. The quotes below capture the participants' attitude toward and behavior regarding open data challenges:

\footnotetext{
"Honestly, when I first heard that Federal agencies required researchers to make all the raw data available to the public I thought: "Really? This is useless and opens the door for a lot of plagiarism." I still feel that way a little bit. It's one
} 
thing to have open access journals where everybody has the chance to download the paper, but making data available (even after the paper has been published) is a little bit too risky. As an editor of an international journal, we see all sorts of plagiarism, and I believe that having that available for everybody to access is not a good idea. I don't make any data available until after the paper has been published."

"I have concerns in making data available prior to true completion of the research (i.e., preparation of the manuscript) for two reasons: 1) research is highly competitive, and publicly available data is indeed available to everyone including competitors in the US and beyond; 2) data should be curated to be useful. Putting up raw data that isn't properly annotated and organized is useless for all parties. "

"What are the challenges? We have A LOT of data! It is a lot of work to prepare the files to make them public."

While the responses represent only a small segment of the institution's research population, the focus group participants underscored that even when researchers share, it is frequently a response to external mandates and not because of a commitment to open data sharing.

\section{Responses to USU's efforts}

The Sponsored Programs Office and the Data Librarian send PIs emails each year at the anniversary of their award to remind the PI of their responsibility to comply with the terms of their award to make data and publications openly available. Three survey questions asked researchers specifically about these email messages. 
First, respondents were asked if the emails they received from Sponsored Programs and from the Data Librarian were helpful. Of the 27 respondents, 20 (74.07\%) strongly agreed and five (18.52\%) somewhat agreed that the email was helpful. Two respondents did not answer the question. Responses did not vary among years of experience of the researcher.

Not all respondents may have received an email from the Data Librarian or remembered receiving one. If they were in the first year of their award, they would not have received a follow up email from the Data Librarian reminding them to deposit data. For the 17 respondents indicating they did receive such an email, $11(64.71 \%)$ strongly agreed with the statement, 5 (29.41\%) somewhat agreed, and $1(5.88 \%)$ somewhat disagreed. The distribution of responses according to the years of experience as a researcher is noteworthy. Of the five "somewhat agree" responses, four came from researchers with 11-15 years of experience. The finding indicates this group may need a different approach.

Figure 4 below compares the percentage of respondents believing the emails were helpful.

\section{[Insert Figure 4]}

Second, respondents were asked to indicate if they understood how to respond to the emails received from Sponsored Programs and the Data Librarian. 
When asked if they understood how to respond to the email from Sponsored Programs, the response was again mostly positive. Thirteen (48.15\%) strongly agreed, 7 (25.93\%) somewhat agreed, 5 respondents $(18.52 \%)$ somewhat disagreed. Again, the results were fairly equally distributed across the years of experience of researchers. When asked if they understood how to respond to the email from the Data Librarian, responses follow the same pattern, with the researchers with 11-15 years of experience in the "somewhat agree" category, and 11 (64.71\%) strongly agreeing, 4 (23.53\%) somewhat agreeing, and 2 (11.76\%) neither agree nor disagree. Figure 5 indicates the percentage of respondents for each category.

\section{[Insert Figure 5]}

Finally, the researchers were asked if the emails explained how they could find help. Twenty-seven people responded to this question regarding the email from Sponsored Program's email. Of these respondents, $16(59.26 \%)$ strongly agreed that the email explained how to find help, $8(29.63 \%)$ somewhat agreed, $1(3.70 \%)$ neither agreed nor disagreed, and $2(7.41 \%$ somewhat disagreed. Seventeen people responded to the question about the email from the Data Librarian and of these respondents, $11(64.71 \%)$ strongly agreed, 5 (29.41\%) somewhat agreed, and $1(5.88 \%)$ neither agreed nor disagreed that the email explained how to find help.

Figure 6 shows the percentage of respondents and level of agreement to the question.

\section{[Insert Figure 6]}


Researchers were asked if Sponsored Programs or the Library could better facilitate efforts to meet agency mandates. Thirteen of $27(48.15 \%)$ responded yes and $14(51.85 \%)$ responded no. When examined by years as a researcher, a higher percentage of respondents in the range of 1120 years as a researcher responded "yes" to this question. Table 1 shows the percentage of responses by years as a researcher.

\section{[Insert Table 1]}

While the OAFG participants were not enthusiastic about open data sharing, they were unanimously supportive of the efforts made by the Library, Research Office, and Sponsored Projects to ensure compliance with funder mandates. One of the notable themes coded in the qualitative data was "Praise for the Data Librarian, the library, and the research office" which appeared in 16 separate statements from participants. The qualitative data did not include any negative statements regarding current efforts, and only included six statements regarding what actions USU could take to improve future services. Some of the statements made in support of the current efforts include:

\footnotetext{
"I had a positive experience in managing the awards through USU. In my opinion, our SPO office does a great job helping us with the process.

... for two of [my] awards, have I worked with SPO to meet data deposition requirements. In both cases, they were very helpful."
}

“What helps me? Betty!!! She is great! As [another participant] mentioned, when I have to upload anything, Betty is my first point of contact. I know that I get excellent information from her." 
"I think our library is doing a great job. They even have a template for the "read me" file. They are great! I think that the process is painful because it takes a lot of time, but the library makes it easier for everybody."

All of the OAFG participants appreciate the annual reminder to deposit data and consider the Data Librarian and SPO to be a valuable resource. When asked how the Library, Research Office, and Sponsored Projects could improve research support some ideas offered included paying author fees for open access publishing, additional data curation training, and depositing publications to repositories on behalf of researchers.

\section{Discussion}

The assessment of the services offered by the Research Office, Sponsored Programs, and the Library offered insight into how a portion of the population served responds to funder requirements to deposit data and publications and the USU's efforts to support them.

\section{Behavior of the Researcher and Researcher Concerns and Challenges}

USU developed the program to facilitate researcher compliance with funder mandates to make data and publications open. This assessment of the program reveals the researchers who responded are making data publicly available but may be doing so with some reservations. Comments from the focus group and the survey reveal concerns and challenges.

Among the challenges researchers face when sharing data and publications are concerns regarding plagiarism, properly managing data during a project, and describing it. One researcher 
commented on concerns about others understanding the details of the dataset and feeling the need to be in direct contact with those using the data because of this:

\begin{abstract}
“And no, I don't make my data publicly available unless someone asks me to do so, largely because it takes time. I almost always share data with people who request via email. And, honestly, regardless of how good the metadata are, I'm not sure I'd have a lot of confidence with people using my datasets without being in email contact with me anyway about study details - maybe it's different for people in more controlled laboratory settings but my research takes place in field settings outdoors where there are so many unmeasured variables and environmental factors that are important to consider when analyzing and interpreting data."
\end{abstract}

This reluctance to share data openly is a concern and is something USU will want to address as having data available is essential to reproducible science. As part of an effort to increase awareness of the importance of data management, USU is hosting a half day "Datapalooza" event and one session is devoted to reproducibility. While the majority of researchers have at least once made data publicly available, it is noticeable from comments researchers lack enthusiasm for this activity.

Another statement illustrates the reluctance of one researcher to share data due to fear of plagiarism:

\footnotetext{
"Honestly, when I first heard that Federal agencies will require to make all the raw data available to the public I thought: "really? This is useless and opens the
} 
door for a lot of plagiarism." I still feel that way a little bit. It's one thing to have open access journals where everybody has the chance to download the paper, but making data available (even after the paper has been published) is a little bit too risky...As an Editor of an international journal we see all sort of plagiarism and I believe that having that available for everybody to access is not a good idea. I don't make any data available until after the paper has been published."

Time appears to be a barrier to researchers. In both focus group and survey comments researchers mentioned the amount of time it takes to prepare data and publications for deposit to repositories. Time also is an issue in terms of how long it takes to generate or gather data. From the survey, the data show researchers indicating needing up to six years after the close of their award to have data ready to deposit in a public repository. Focus groups participants expressed concerns about perceived expectations to make data publicly available before they were comfortable doing so, such as preliminary data or data from results that have not yet been published. This finding indicates a need for USU to better inform faculty and researchers about what the expectations of funders are.

The sheer amount of time to manage the requirements to make data and publications open was described in a comment in the survey:

"As a researcher and faculty member, I am grateful for all that Sponsored Programs, the Research Office, and Library are doing to help with this. The issue is that if you are a productive researcher; running a lab; mentoring students; writing publication as lead, with your students as lead; writing grants to fund all of this... all the while teaching and doing service... then there really is limited 
time to get all that data into databases. In the past I have had an undergraduate researcher assist with this and I need to keep doing that. One strategy would be to literally build money into my next NSF grant to hire an undergraduate researcher to do just this."

Other time related challenges mentioned included the sheer amount of data that had to be described and delivered for archiving to the Data Librarian, curating and organizing the data so it is useful, and navigating tools with interfaces that are not intuitive for describing data.

Researchers mentioned using specific tools to help them in managing data, although neither the survey nor the focus group specifically asked about tools or data repositories. They mentioned using a variety of repositories, such as FigShare, Gene Expression Omnibus, Digital Commons, Knowledge Network for Biocomplexity (KNB) and tools such as the DMP Tool, Morpho and Metavist. It would be useful to further explore the use of these and other resources at USU and determine if outreach and training would be useful.

\section{Researcher Response to Sponsored Programs and Library Efforts}

The data from the survey shows researchers who responded to the survey feel the email communications from Sponsored Programs and the Data Librarian are helpful, clear, and provide information for finding assistance. Comments from the survey and the focus groups indicate researchers appreciate the support they receive to help them remain compliant with funder requirements. Researchers specifically mentioned they could call the Data Librarian to get help with templates available for readme files, preparing metadata, and writing data management 
plans. Sponsored Programs and the Library both received praise for the reminders in the comments, indicating the reminders were helpful for researchers.

\section{Suggestions for Improvements to the Program}

While expressing satisfaction with Sponsored Programs and the Library for the current efforts to support researchers as they comply with funder mandates, those responding to the survey were nearly evenly split when asked if Sponsored Programs or the Library could better facilitate their efforts to meet agency mandates to deposit data and publications. Researchers who have 11 to 20 years responded 'yes' more often than other brackets. This result may be an area for further investigation to learn how the system could be improved.

Some suggestions were for services or practices that are currently in place or available and illustrate a need for improved communication on the part of USU's Data Management Team. Low hanging fruit that is currently implemented or can easily be implemented includes:

(1) Meet with the Data Librarian after receiving an award to make a concrete plan to make data public and deposit awards

(2) Checking to see what publications can be uploaded and updating PI records accordingly

(3) Custom support for any agency requirements

(4) Sending reminders beyond the close of the award, until the PI notifies the Data Librarian that all data and publications related to the award have been deposited. 
Researchers pointed out that requirements of the funders are not clear to them and they would appreciate clarifications. The Library recently redesigned the RDMS page for agency data and publication requirements and will begin to tailor reminder emails to include links to resources for each PI's agency information about requirements.

A few requests are beyond the current scope of what is currently offered by USU. Several researchers stated they would appreciate help uploading their publications into agency repositories, including converting publications to pdf/A format. Along with this, one researcher thought it would be helpful to link the publications that are in the funder sites to the University's faculty activity reporting system.

Researchers also commented in the focus groups about the importance of publishing in open access journals and wanting the Research Office or Library to help support the cost of publishing in these journals. Researchers discussed including fees in their award proposals for open access. This finding is interesting considering the OSTP memo states that publications resulting from federally funded research will be made freely available after an embargo period through the funder's repository, regardless of publication in an open access journal. Assistance with making data available was also mentioned, specifically requests for someone to upload the data to external data repositories. One researcher commented that it would be nice to have a repository that was designed for research data rather than the USU's current repository, Digital Commons.

\section{Conclusions and Future Directions}


The data collected only represents a portion of the researchers Sponsored Programs and the Library work with to support compliance with funder mandates and cannot be extrapolated to the entire population. It can be used to provide USU with insights into the effectiveness of and for improvements to the program.

As mentioned earlier, enthusiasm for making data open is lacking even though most researchers have made their data public least once. There is work to be done to encourage making data open. Further assessment in this area would help determine how to address some of these issues and understand the researchers' hesitancy.

Researchers responding appreciate the support offered but have questions about the requirements of their awards. Sponsored Programs and the Library will be working on improved communication about existing services and agency expectations to clarify these issues for PIs. Additionally, researchers are sharing data, but with some reluctance. Work to develop a culture of responsible data stewardship is underway with campus events and training. These data show which topics would be well suited for future sessions, including when data should be released, data citation and licensing, and effective methods for describing research data. 


\section{References Cited}

Association of Research Libraries (ARL). (2020, January 9). ARL Comments on Draft NIH Policy for Data Management and Sharing. Association of Research Libraries. https://www.arl.org/news/arl-comments-on-draft-nih-policy-for-data-management-andsharing/

Broadbent, J. R., Payant, A., Peterson, K., Rozum, B., \& Woolcott, L. (2018). A Campus Partnership to Foster Compliance with Funder Mandates. The Journal of Academic Librarianship, 44(1), 96-104. https://doi.org/10.1016/j.acalib.2017.10.002

Gaiser, T. J. (1997). Conducting On-Line Focus Groups: A Methodological Discussion. Social Science Computer Review, 15(2), 135-144. https://doi.org/10.1177/089443939701500202

Greenbaum, T. (2008). The case against internet focus groups. https://groupsplus.com/pages/case2.htm

Hamilton, R. J., \& Bowers, B. J. (2006). Internet Recruitment and E-Mail Interviews in Qualitative Studies. Qualitative Health Research, 16(6), 821-835. https://doi.org/10.1177/1049732306287599

Han, J., Torok, M., Gale, N., Wong, Q. J., Werner-Seidler, A., Hetrick, S. E., \& Christensen, H. (2019). Use of Web Conferencing Technology for Conducting Online Focus Groups Among Young People With Lived Experience of Suicidal Thoughts: Mixed Methods Research. JMIR Mental Health, 6(10), e14191. https://doi.org/10.2196/14191

Hoffman, D. L., Novak, T. P., \& Stein, R. (2013). The digital consumer. In The Routledge Companion to Digital Consumption (pp. 28-38). Scopus. 
https://www.scopus.com/inward/record.uri?eid=2-s2.0-

84888037245\&partnerID=40\&md5=b4ce5c403de88074e1e01577ce9e64e7

Holdren, J. (2013). Memorandum for the Heads of Executive Departments and Agencies:

Increasing Access to the Results of Federally Funded Scientific Research.

https://obamawhitehouse.archives.gov/sites/default/files/microsites/ostp/ostp_public_acce ss_memo_2013.pdf

Kenny, A. J. (2005). Interaction in cyberspace: An online focus group. Journal of Advanced Nursing, 49(4), 414-422. https://doi.org/10.1111/j.1365-2648.2004.03305.x

Krueger, R. A. (1995). The Future of Focus Groups. Qualitative Health Research, 5(4), 524530. https://doi.org/10.1177/104973239500500412

Matthews, J., \& Cramer, E. (2008). Using Technology to Enhance Qualitative Research with Hidden Populations. The Qualitative Report, 13(2), 301-315.

O'Connor, H., \& Madge, C. (2003). Focus groups in cyberspace: Using the Internet for qualitative research. Qualitative Market Research: An International Journal, 6(2), 133143. https://doi.org/10.1108/13522750310470190

Popper, K. (2005). The Logic of Scientific Discovery. http://strangebeautiful.com/othertexts/popper-logic-scientific-discovery.pdf

Ramo, D. E., Meacham, M., Thrul, J., Belohlavek, A., Sarkar, U., \& Humfleet, G. (2019). Exploring Identities and Preferences for Intervention Among LGBTQ+ Young Adult Smokers Through Online Focus Groups. Journal of Adolescent Health, 64(3), 390-397. https://doi.org/10.1016/j.jadohealth.2018.09.022

Redd, K., Steen, K., Nusser, S., Smith, T., Walters, T., Chasen, J., Luther, J., \& Reecy, J. (2019). Accelerating Public Access to Research Data Workshop Report. Joint Publications by the 
Association of Public and Land-grant Universitites and Association of American Universities. https://www.aplu.org/projects-and-initiatives/research-science-andtechnology/public-access/workshop-on-public-access-report-aplu-aau-2019.pdf

Robinson, N. (1999). The use of focus group methodology - With selected examples from sexual health research. Journal of Advanced Nursing, 29(4), 905-913. https://doi.org/10.1046/j.1365-2648.1999.00966.x

Sim, J. (1998). Collecting and analysing qualitative data: Issues raised by the focus group. Journal of Advanced Nursing, 28(2), 345-352. https://doi.org/10.1046/j.13652648.1998.00692.x

Stewart, D. W., \& Shamdasani, P. (2017). Online Focus Groups. Journal of Advertising, 46(1), 48-60. https://doi.org/10.1080/00913367.2016.1252288

Stewart, K., \& Williams, M. (2005a). Researching online populations: The use of online focus groups for social research. Qualitative Research, 5(4), 395-416. https://doi.org/10.1177/1468794105056916

Stewart, K., \& Williams, M. (2005b). Researching online populations: The use of online focus groups for social research. Qualitative Research, 5(4), 395-416. https://doi.org/10.1177/1468794105056916

Stover, C. M. (2012). The Use of Online Synchronous Focus Groups in a Sample of Lesbian, Gay, and Bisexual College Students: CIN: Computers, Informatics, Nursing, 30(8), 395399. https://doi.org/10.1097/NXN.0b013e3182636921

Tuttas, C. A. (2015). Lessons Learned Using Web Conference Technology for Online Focus Group Interviews. Qualitative Health Research, 25(1), 122-133. https://doi.org/10.1177/1049732314549602 
Twinn, D. S. (1998). An analysis of the effectiveness of focus groups as a method of qualitative data collection with Chinese populations in nursing research. Journal of Advanced Nursing, 28(3), 654-661. https://doi.org/10.1046/j.1365-2648.1998.00708.x

Vitale, C. R. H. (2016). Is Research Reproducibility the New Data Management for Libraries? Bulletin of the Association for Information Science and Technology, 42(3), 38-41. https://doi.org/10.1002/bul2.2016.1720420313

Watson, M., Peacock, S., \& Jones, D. (2006). The analysis of interaction in online focus groups. International Journal of Therapy and Rehabilitation, 13(12), 551-557. https://doi.org/10.12968/ijtr.2006.13.12.22471

Williams, S., Clausen, M. G., Robertson, A., Peacock, S., \& McPherson, K. (2012). Methodological Reflections on the Use of Asynchronous Online Focus Groups in Health Research. International Journal of Qualitative Methods, 11(4), 368-383. https://doi.org/10.1177/160940691201100405

Zwaanswijk, M., \& van Dulmen, S. (2014). Advantages of asynchronous online focus groups and face-to-face focus groups as perceived by child, adolescent and adult participants: A survey study. BMC Research Notes, 7(1), 756. https://doi.org/10.1186/1756-0500-7-756 


\title{
Appendix A: Survey Instrument
}

\author{
Managing Data and Publication Requirements of Federal Awards
}

Start of Block: Informed Consent

Q1

\section{Introduction}

You are invited to participate in a survey conducted by Interim Vice President for Research Lisa Berreau and Dean of Libraries Brad Cole at Utah State University . The purpose of this research is to evaluate the program the USU Research Office and Merrill-Cazier Library have developed to provide support and services to researchers who are managing federally funded awards with requirements to make publications and/or data publicly and openly accessible. This survey will help the Research Office and the Library gain insight into how the program and services can be improved to better support USU researchers.

\section{Procedures}

Your participation will involve answering questions related to managing your publications and data you produce that are associated with your sponsored award. Most questions are multiple choice with a few open-ended questions at the end of the survey. Your total participation in this survey is expected to be no longer than 10minutes, depending on your responses.

We invited about 80 people to participate in this research study. The participant base chosen are Utah State University faculty members who received awards with data sharing requirements after 10/01/2016.

\section{Risks}

This is a minimal risk research study. That means that the risks of participating are no more likely or serious than those you encounter in everyday activities. Though the survey is anonymous and will not ask you to reveal your identity, there is minimal risk to you as a participant may be identifiable because of self-identifying information you provide in your responses.

\section{Benefits}

Although you will not directly benefit from this study, it has been designed to learn more about how the USU Research Office and the Merrill-Cazier Library can support researchers in their efforts to meet the compliance funders require. Your responses will help us evaluate our program.

\section{Confidentiality}

We will make every effort to ensure that the information you provide as part of this study remains confidential. Your identity will not be revealed in any publications, presentations, or reports resulting from this research study. However, it may be possible for someone to recognize 
your particular story/situation/response due to your responses inadvertently providing details specific to your person. To protect anonymity, one of the researchers who is not an employee of Utah State University will redact responses that inadvertently self-identify.

We will collect your responses through a Qualtrics survey. Online activities always carry a risk of a data breach, but we will use systems and processes that minimize breach opportunities. We will program the survey so that responses are anonymized. When you click the link to view the survey online in Qualtrics, your identifying information (name, email, and IP address) will be disconnected from your responses. There will be no way to match identifying information with responses except if you inadvertently self-identify.

It is also possible, but unlikely, that state or federal officials may require us to share the information you give us from the study to ensure that the research was conducted safely and appropriately. In this case, we will only share your information if law or policy requires us to do so.

\section{Voluntary Participation \& Withdrawal}

Your participation in this research is completely voluntary. If you agree to participate now and change your mind later, you may withdraw at any time by simply closing the survey window. If you choose to withdraw after we have already collected information about you, please note that completely anonymous participation cannot be withdrawn, as you will be unable to determine whose data is whose. If you decide not to participate, the services you receive from Research and Data Management Services in the University Libraries will not be affected in any way. However, your participation is very valuable in determining if we are meeting your needs.

\section{Compensation}

You will not receive compensation for your participation in this research study. Participating in this survey will not cost you anything other than your time.

\section{Informed Consent}

By continuing on to the survey, you agree to participate in this study. You indicate that you understand the risks and benefits of participation, and that you know what you will be asked to do. You also agree that you have asked any questions you might have and are clear on how to stop your participation in the study if you choose to do so.

\section{End of Block: Informed Consent}

Start of Block: Intro

Q1.1 In February 2013, the White House issued a memorandum requiring federal agencies with over $\$ 100 \mathrm{M}$ in R\&D to make the direct results of federally funded scientific research, including peer-reviewed publications and digital data, available to the public. In 2016 USU began a service in which researchers with federal award impacted by this mandate were notified at the time of the award and reminded annually of the sponsor requirements to make x publications available in the sponsor's repository and data available per the terms of the researcher's data management 
plan. The Office of Research and the Merrill-Cazier Library seek feedback from you to improve this process.

\section{End of Block: Intro}

\section{Start of Block: Block 2}

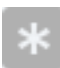

Q2.1 What is the total number of years you have been a researcher (count only the years after your terminal degree)

\section{End of Block: Block 2}

\section{Start of Block: Block 3}

Q3.1 How many awards have your received from sponsors that have required you to make publications available in the sponsor's public access repository (PubMed, NSF Public Access Repository, PubSpace, etc.)?

$$
\begin{aligned}
& 0-3(1) \\
& 4-7(2) \\
& 8-10(3) \\
& \text { more than } 10 \text { (4) }
\end{aligned}
$$

Q3.2 How many awards have your received from sponsors that have required you to make data publicly available in a repository, such as Dryad, DigitalCommons@USU, GenBank, Zenodo, etc.?

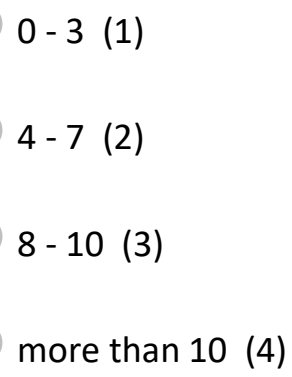


Q3.3 Indicate how often you make your data publicly and openly available (i.e., in a data repository) under the following circumstances:

\begin{tabular}{|c|c|c|c|c|c|}
\hline & Never (1) & $\begin{array}{l}0-3 \text { times in } \\
\text { my career }(2)\end{array}$ & $\begin{array}{l}4-7 \text { times in } \\
\text { my career }(3)\end{array}$ & $\begin{array}{l}8-10 \text { times in } \\
\text { my career }(8)\end{array}$ & $\begin{array}{c}\text { More than } 10 \\
\text { times in my } \\
\text { career }(9)\end{array}$ \\
\hline $\begin{array}{l}\text { As part of a } \\
\text { requirement to } \\
\text { publish with a } \\
\text { journal (1) }\end{array}$ & & & & & ) \\
\hline $\begin{array}{l}\text { To satisfy a } \\
\text { funder, but not } \\
\text { associated with } \\
\text { a journal } \\
\text { publication (2) }\end{array}$ & & & & & \\
\hline $\begin{array}{l}\text { Just to make } \\
\text { the data open } \\
\text { and public, and } \\
\text { not associated } \\
\text { with an article } \\
\text { or because of } \\
\text { funder } \\
\text { requirements } \\
\text { (3) }\end{array}$ & 0 & 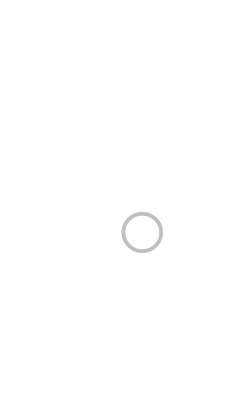 & $\cap$ & $\bigcirc$ & ) \\
\hline
\end{tabular}


Q3.4 Indicate how often you have deposited publications to the following public access repositories:

\begin{tabular}{|c|c|c|c|c|c|}
\hline & Never (1) & $\begin{array}{l}0-3 \text { times in } \\
\text { my career }(2)\end{array}$ & $\begin{array}{l}4-7 \text { times in } \\
\text { my career }(3)\end{array}$ & $\begin{array}{l}8-10 \text { times in } \\
\text { my career }(4)\end{array}$ & $\begin{array}{c}\text { More than } 10 \\
\text { times in my } \\
\text { career }(5)\end{array}$ \\
\hline $\begin{array}{l}\text { NIH PubMed } \\
\text { (1) }\end{array}$ & & & & & ) \\
\hline $\begin{array}{c}\text { NASA } \\
\text { PubSpace (2) }\end{array}$ & & & & & $\bigcirc$ \\
\hline $\begin{array}{c}\text { NSF Public } \\
\text { Access } \\
\text { Repository (3) }\end{array}$ & & & & & \\
\hline $\begin{array}{l}\text { US Dept of } \\
\text { Energy } \\
\text { PAGES (4) }\end{array}$ & & & & & \\
\hline $\begin{array}{l}\text { Other: Please } \\
\text { Specify (5) }\end{array}$ & & & & & 0 \\
\hline $\begin{array}{l}\text { Other: Please } \\
\text { Specify (6) }\end{array}$ & & & & & \\
\hline
\end{tabular}

Q3.5 Using the sliding scale below, please indicate, in years, how long after the close of your award you anticipate producing or you have generally produced journal publications. If more than 20 years, indicate 20 .

$$
\begin{array}{llllllllll}
0 & 2 & 4 & 7 & 9 & 11 & 13 & 16 & 18 & 20
\end{array}
$$

Journal Publications ()

Q3.6 Using the sliding scale below, please indicate, in years, how long after the close of your award you anticipate having your final data ready for deposit to a public repository. If more than 20 years, indicate 20 .

$$
\begin{array}{lllllllllll}
0 & 2 & 4 & 6 & 8 & 10 & 12 & 14 & 16 & 18 & 20
\end{array}
$$


Q4.1 Each year on the anniversary of your award Sponsored Programs sends you an email reminding you of the sponsor's requirements to deposit data and publications, per the terms of your award. The email reads:

\section{"Hello}

This message serves as a friendly reminder that federal sponsors have implemented data management policies with which you must comply as part of your active federal award with $<$ YYur Award Here >> To ensure compliance with these policies, USU strongly recommends that you regularly update the USU Primary Metadata Document (PMD) associated with your award. Attached is the latest version of your PMD. If you have any updates to make to your PMD, please send the updated PMD to betty.rozum@usu.edu. If you have any questions about your data management obligations or PMD, please contact Betty Rozum in the Merrill-Cazier Library(betty.rozum@usu.edu; 7-2632).

Thank you, Sponsored Programs " 
Q4.2 Thinking about the email above, please indicate if:

\begin{tabular}{l|cccc} 
Strongly agree & $\begin{array}{c}\text { Somewhat } \\
\text { agree (2) }\end{array}$ & $\begin{array}{c}\text { Neither agree } \\
\text { nor disagree } \\
(1)\end{array}$ & $\begin{array}{c}\text { Somewhat } \\
\text { disagree (4) }\end{array}$ & $\begin{array}{c}\text { Strongly } \\
\text { disagree (5) }\end{array}$ \\
\hline $\begin{array}{c}\text { The email is a } \\
\text { helpful } \\
\text { reminder (1) }\end{array}$ \\
$\begin{array}{c}\text { I understand } \\
\text { how to } \\
\text { respond to the } \\
\text { email (2) }\end{array}$ \\
$\begin{array}{c}\text { The email } \\
\text { explains how I } \\
\text { can find help } \\
\text { (3) }\end{array}$ \\
$\begin{array}{c}\text { Other, please } \\
\text { comment (4) }\end{array}$
\end{tabular}

Q4.3 Thinking about the communication(s) you receive from Sponsored Programs about fulfilling the mandates required by your award sponsor, do you have comments or suggestions for us? 
Q4.4 After receiving the email from Sponsored Programs, you may receive a personalized email from USU's data librarian Betty Rozum that follows up on your award. Have you received an email from Betty Rozum following up on your award?

Yes (1)

No (2)

\section{Display This Question:}

Q4.5 After receiving the email from Sponsored Programs, you you indicated you received a personalized email from USU's data librarian Betty Rozum that follows up on your award. Thinking about this email, please indicate the degree to which you agree or disagree with the following statements:

\begin{tabular}{|c|c|c|c|c|c|}
\hline & $\begin{array}{l}\text { Strongly agree } \\
\text { (1) }\end{array}$ & $\begin{array}{l}\text { Somewhat } \\
\text { agree (2) }\end{array}$ & $\begin{array}{c}\text { Neither agree } \\
\text { nor disagree } \\
\text { (3) }\end{array}$ & $\begin{array}{l}\text { Somewhat } \\
\text { disagree (4) }\end{array}$ & $\begin{array}{c}\text { Strongly } \\
\text { disagree (5) }\end{array}$ \\
\hline $\begin{array}{l}\text { The email is a } \\
\text { helpful } \\
\text { reminder (1) }\end{array}$ & & & & & \\
\hline $\begin{array}{l}\text { I understand } \\
\text { how to } \\
\text { respond to the } \\
\text { email (2) }\end{array}$ & & & & & \\
\hline $\begin{array}{l}\text { The email } \\
\text { explains how I } \\
\text { can find help } \\
\text { (3) }\end{array}$ & & & & & \\
\hline $\begin{array}{l}\text { Other, please } \\
\text { comment (4) }\end{array}$ & 0 & 0 & 0 & 0 & 0 \\
\hline
\end{tabular}


Q4.6 Thinking about the communication(s) you receive from the Library (Betty Rozum) about fulfilling the mandates required by your award sponsor, do you have comments or suggestions for us?

\section{End of Block: Block 4}

\section{Start of Block: Block 5}

Q14 Could Sponsored Programs and/or the Library better facilitate your efforts to meet your agency's mandates to deposit publications and data?
Yes (1)
No (2)

\section{Display This Question:}

If Could Sponsored Programs and/or the Library better facilitate your efforts to meet your agency's... = Yes

Q15 You indicated Sponsored Programs and/or the Library could better facilitate your efforts to meet your agency's mandates to deposit publications and data. Please give us ideas of what we can do that would help. 
Q16 Please share any additional thoughts or comments you have on our process.

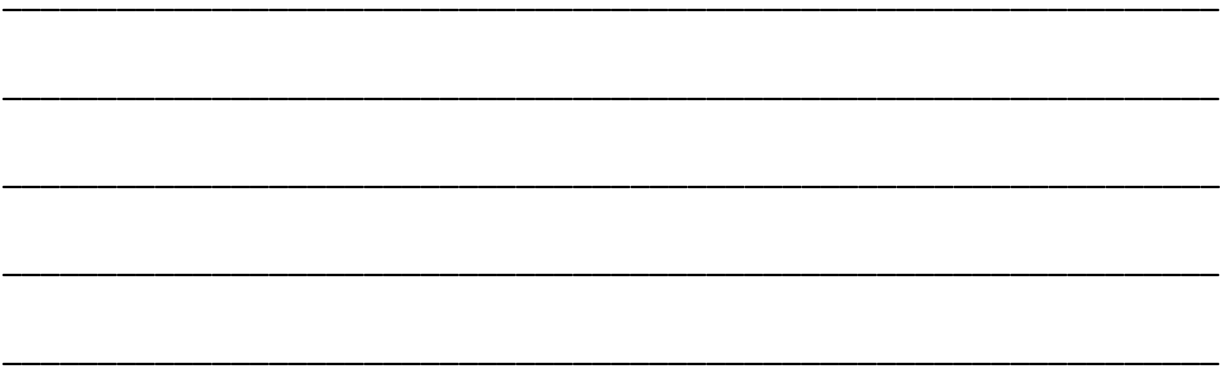




\section{Appendix B: USU Data Repository Focus Group Instrument}

\section{Introductions}

Hello and thank you for participating in the USU Data Repository Assessment Focus Groups! My name is Rebekah Cummings, and I will be moderating the discussion today. We have five discussion threads below where you can comment on various topics, respond to the question prompts, or respond to other commenters. Please feel free to drop into the focus group at any time today to see how the conversation has progressed. Your input is incredibly valuable to help USU improve their data services. In this "Introduction" thread, please tell us:

1) Who has funded your work?

2.) How many times have you been through the award process? Tell us about your experience managing awards.

3.) Where you have deposited your data?

4.) Why did you choose to participle in this focus group today?

\section{Topic 1: Researcher response to funder mandates}

When funders implemented their requirements for data management plans and deposit of your publications to their article repositories, such as the NSF Public Access Repository, what was your reaction? When did you learn about the requirements? How did you learn how to fulfill them?

Many of you have full schedules with research, teaching, and mentoring. How do you keep on top of placing your articles in the appropriate repository and following the terms of your data management plan that the funders require? What helps you? What are challenges?

\section{Topic 2: Researchers practices regarding data and publication deposit}

Can you talk about placing articles in Funder Repositories, such as the NSF PAR, NIH PubMed, etc.? Which repositories have you placed your publications in and what was your experience like?

What challenges did you face? How do you remember to do this? What was confusing? What would help you?

How do you feel about making articles publicly available? Is this added work worth the effort to those who benefit? 
Can you talk about making your data publicly available? How have you made your data available? Have you done this before agencies and journals required you to do this? What issues or concerns do you have with this process?

\section{Topic 3: Research Office and Library Program}

When USU learned of the Funder Mandates, the Research Office and Library partnered to develop support services for research data management to help researchers with these requirements.

Talk about the beginning stages of your proposal and the help you received from Sponsored Programs and/or the Library when you are preparing your award.

After you receive your award, how well do you understand your responsibilities to make your publications and data available? Does the funder make this clear to you? How do you learn about your responsibilities?

What resources did the funder provide? Who taught/showed you about this?

Sponsored Programs and the Library send reminders each year reminding you to deposit data and publications. Have your received these reminders in the past? Do they help you remember to deposit/track data and publications? What frequency would work best? Is there a better format than email?

\section{Topic 4: What would help?}

What problems or questions have you encountered with depositing data and/or publications? Can you think of services that could help you with this?

Which agencies have better systems for depositing publications? Why? What do you like about them? What is confusing? What questions do you have about depositing data? Where do you turn for answers?

Is there anything you would like to say about the services Sponsored Programs, or the Library offers in supporting your award?

\section{Feedback on focus groups (optional but much appreciated)}

Did you enjoy this asynchronous focus group format? Was it preferable to an in-person focus group? What could we have done differently? 


\section{Figures}

Figure 1 Grant Data Management Process; a brief overview demonstrating the process of working with a PI to adhere to their grant award's data sharing requirements

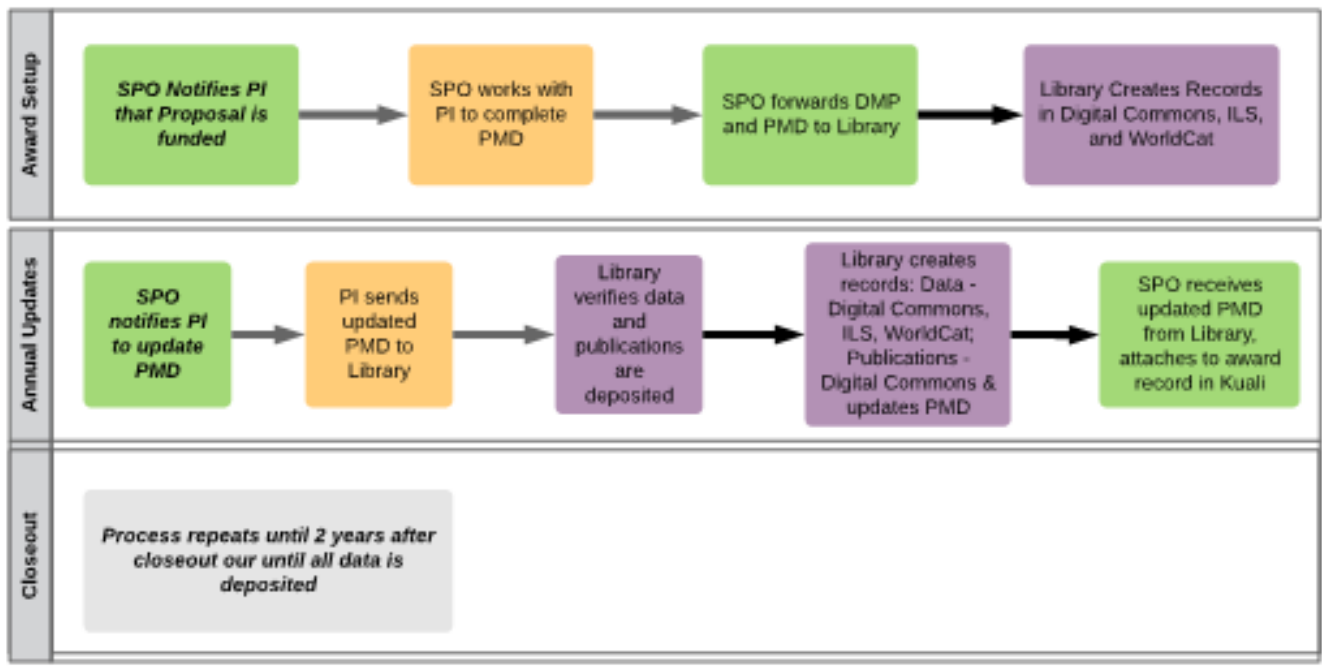

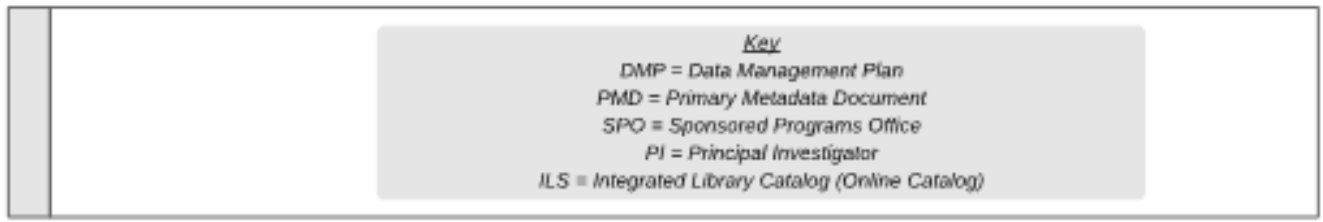


Figure 2: Frequency of Making

How often researchers made data public in order to comply with a funder's requirements or publish with a journal

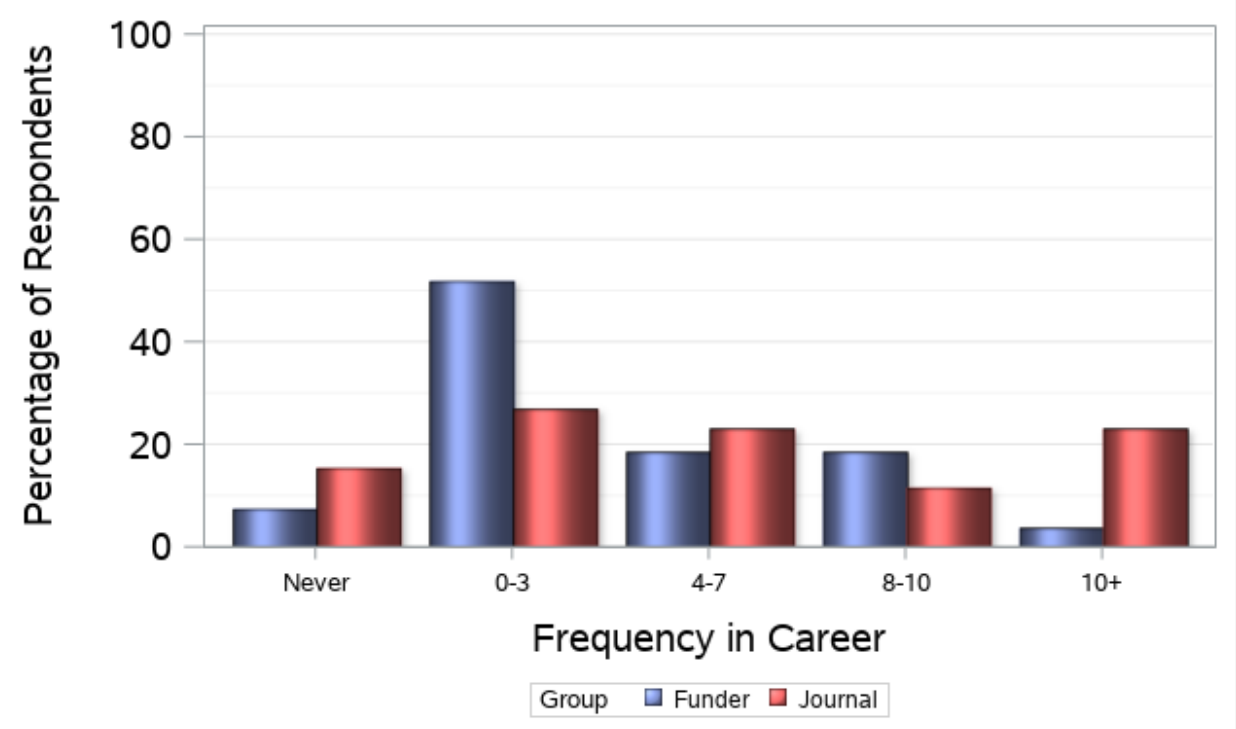

Data Public

Figure 3: Years after close of award to final data deposit

How many years do researchers anticipate needing after the close of their award in order to have data ready to deposit in a public access repository

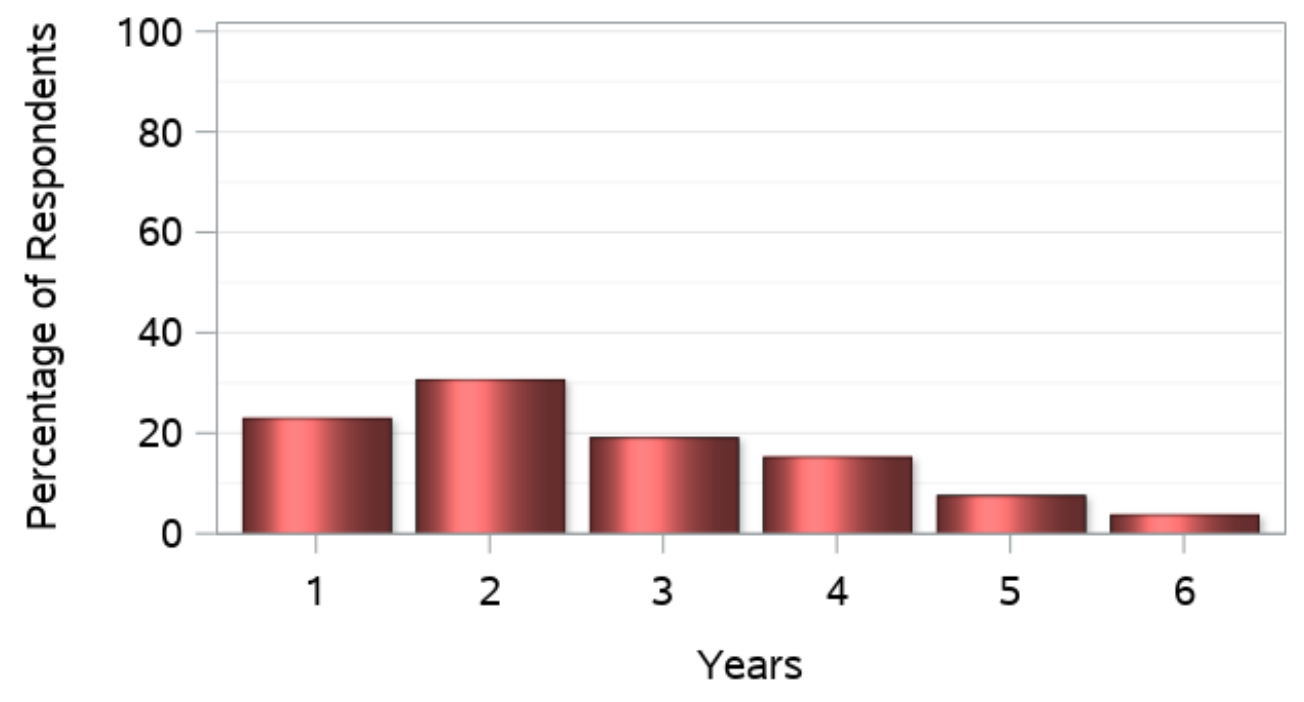


Figure 4: How helpful are emails

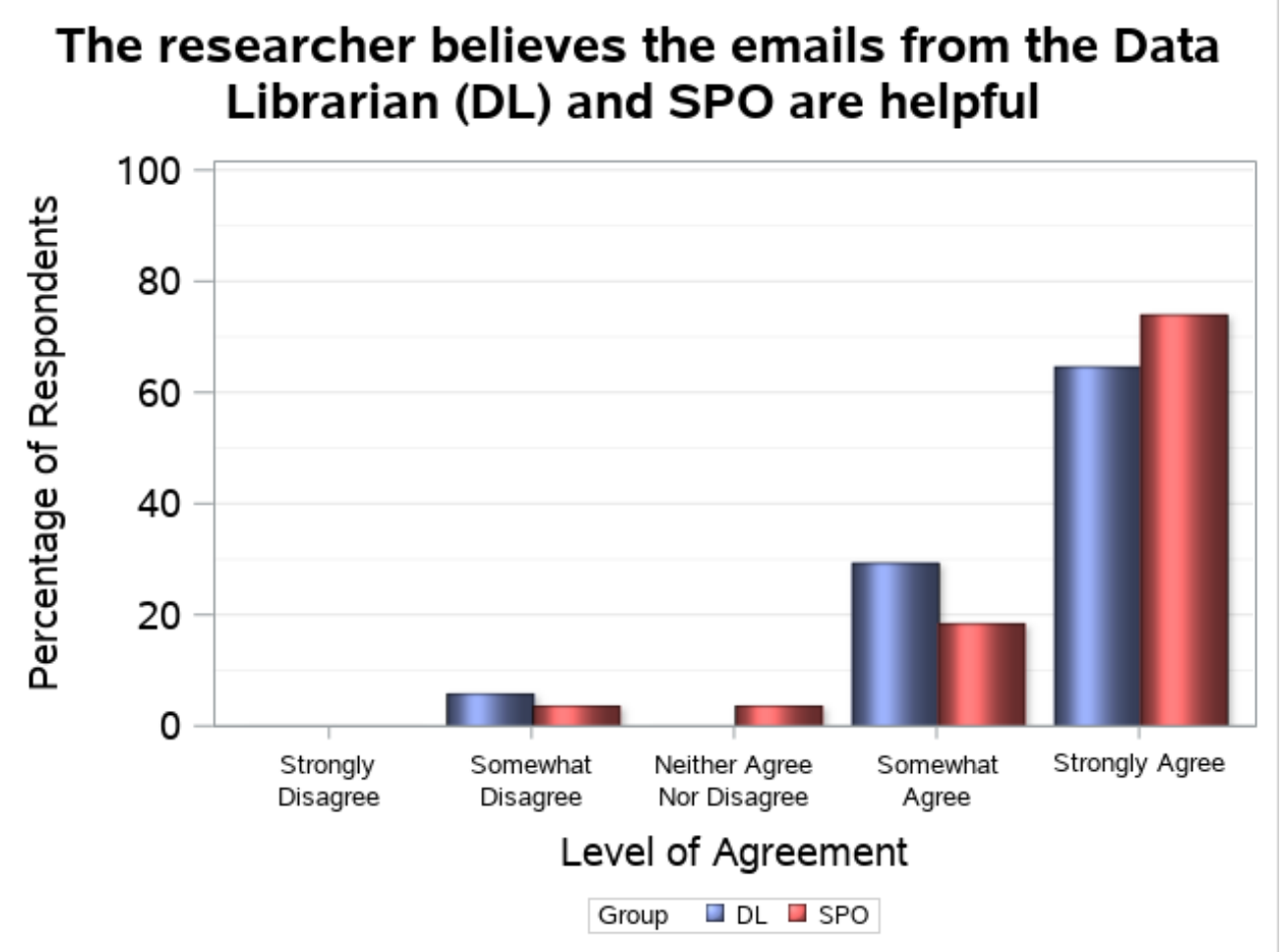

Figure 5: Do researchers understand how to respond to emails?

The researcher understands how to respond to the emails from the Data Librarian (DL) and SPO

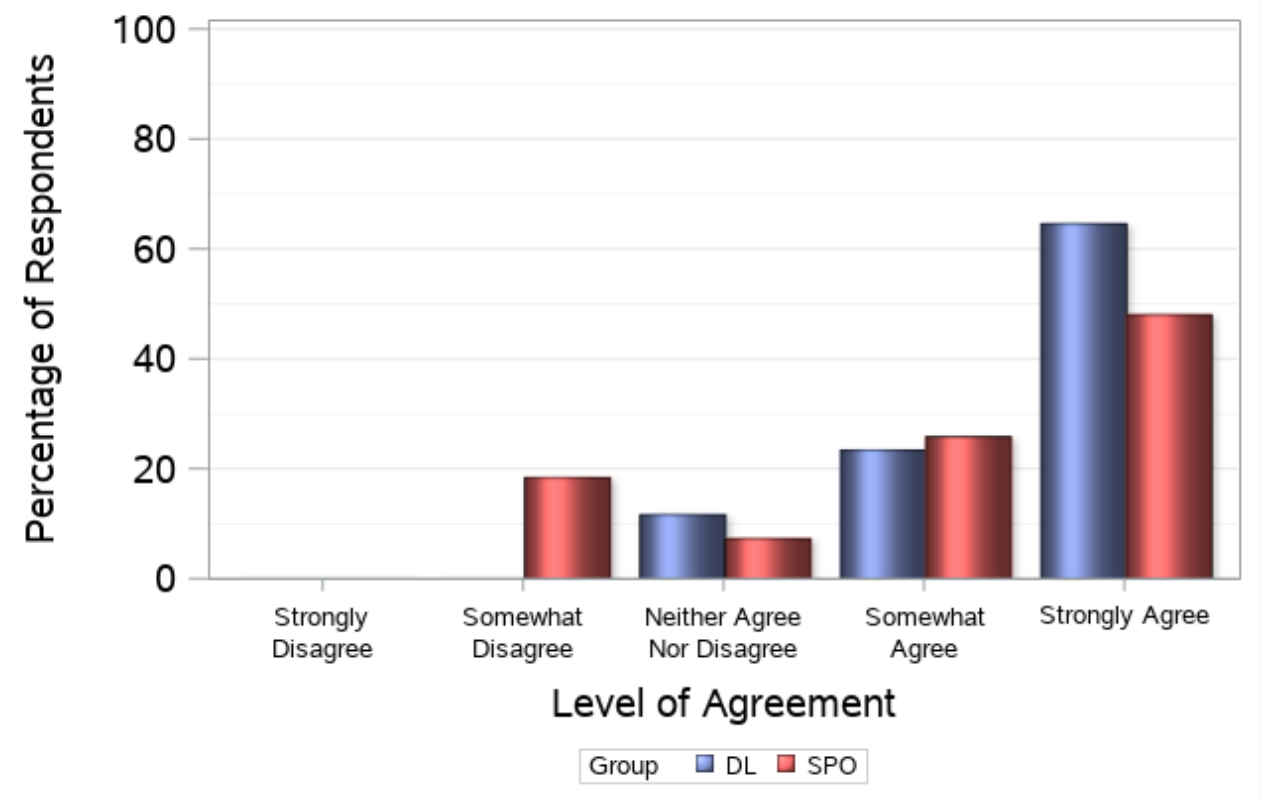

Figure 6: Do emails explain where to find help? 
The emails from the Data Librarian (DL) and SPO explain where the researcher can find help

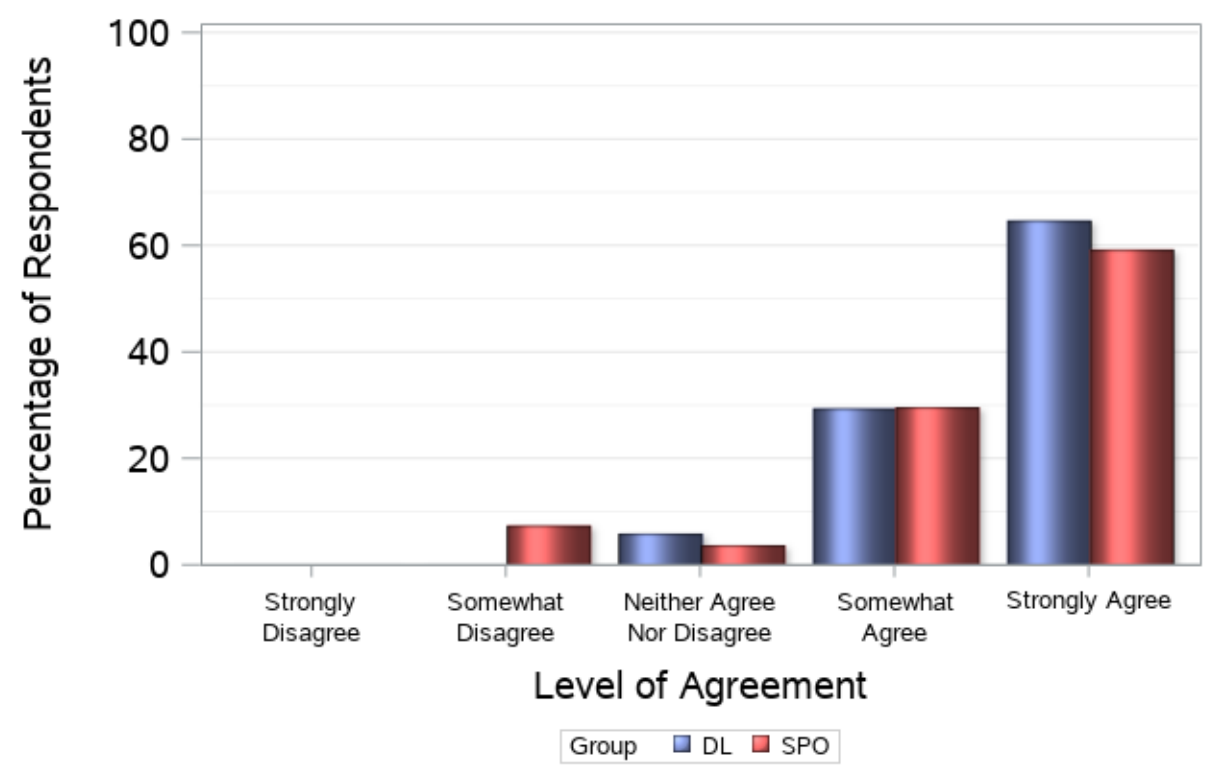

Table 1: Could the library or Sponsored Programs better facilitate efforts to meet mandates?

\begin{tabular}{|c|c|c|c|}
\hline $\begin{array}{l}\text { Key: } \\
\text { Frequency } \\
\text { Percent } \\
\text { Row Percent } \\
\end{array}$ & & & \\
\hline $\begin{array}{l}\text { Could SPO or the lib } \\
\text { deposit publications a }\end{array}$ & $\begin{array}{l}\text { ary bett } \\
\text { nd data }\end{array}$ & Ir effort & $y$ mandates to \\
\hline Years as a Researcher & No & Yes & Total \\
\hline $0-5$ & $\begin{array}{l}1 \\
3.70 \\
100.00\end{array}$ & $\begin{array}{l}0 \\
0.00 \\
0.00\end{array}$ & $\begin{array}{l}1 \\
3.70\end{array}$ \\
\hline $6-10$ & $\begin{array}{l}3 \\
11.11 \\
50.00\end{array}$ & $\begin{array}{l}3 \\
11.11 \\
50.00\end{array}$ & $\begin{array}{l}6 \\
22.22\end{array}$ \\
\hline $11-15$ & $\begin{array}{l}3 \\
11.11 \\
37.50\end{array}$ & $\begin{array}{l}5 \\
18.52 \\
62.50\end{array}$ & $\begin{array}{l}8 \\
29.63\end{array}$ \\
\hline $16-20$ & $\begin{array}{l}0 \\
0.00 \\
0.00\end{array}$ & $\begin{array}{l}2 \\
7.41 \\
100.00\end{array}$ & $\begin{array}{l}2 \\
7.41\end{array}$ \\
\hline
\end{tabular}




\begin{tabular}{|l|l|l|l|}
\hline $21-25$ & 3 & 0 & 3 \\
& 11.11 & 0.00 & 11.11 \\
& 100.00 & 0.00 & \\
\hline $26-30$ & 3 & 1 & 4 \\
& 11.11 & 3.70 & 14.81 \\
& 75.00 & 25.00 & \\
\hline $31-35$ & 1 & 2 & 3 \\
& 3.70 & 7.41 & 11.11 \\
& 33.33 & 66.67 & \\
\hline Total & 14 & 13 & 27 \\
& 51.85 & 48.15 & 100.00 \\
\hline
\end{tabular}


